\title{
A STUDY ON THE ADVERTISEMENTS RELATED TO SLIMMING PRODUCTS IN PRINT MEDIA AND ITS IMPACT AMONG YOUNGSTERS
}

\author{
Dr. P. Sri Jothi ${ }^{1} \square$ (ID), Dr. A Jayanthila Devi ${ }^{2} \square$ (iD \\ Associate Professor, Post-Doctoral Research Fellow, Department of Visual Communication, School of Mass \\ Communication, Vels Institute of Science, Technology and Advanced Studies, Srinivas University, Mangalore, \\ Karnataka, India \\ ${ }^{2}$ Professor, Computer Science and Information Science, Srinivas University, Mangalore, Karnataka, India
}
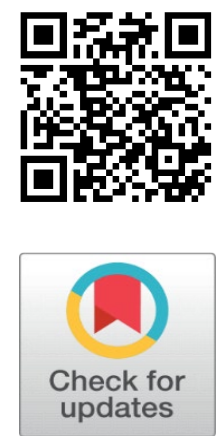

Received 05 December 2021

Accepted 20 February 2022

Published 04 March 2022

\section{CorrespondingAuthor}

Dr. P. Sri Jothi,

sreejoonline@gmail.com

\section{DOI}

10.29121/shodhkosh.v3.i1.2022.69

Funding: This research received no specific grant from any funding agency in the public, commercial, or not-for-profit sectors.

Copyright: (C) 2022 The Author(s). This is an open access article distributed under the terms of the Creative Commons Attribution License, which permits unrestricted use, distribution, and reproduction in any medium, provided the original author and source are credited.

OPEN ACCESS

\section{ABSTRACT}

Today's trend there is a noticeable raise in the frequency of advertisements of slimming and weight loss products in print media. Being slim has become an obsession for many people in the last couple of decades. Recently many people do not have conscious about slim toned bodies in naturally, so generally these people should constantly be vigilant in methods that will help lose some fat like diet and other methods to conform to current ideals. Many slimming product sellers employ promotion as a tool to persuade youngsters by inculcating creative ideas. These advertisements are highly exaggerated, and they can easily influence the people especially youngsters who are conscious about their appearance. The major objective of this is to analyze the content of various slimming advertisements in print media and to find out its impact among youngsters. The research methodologies used are content analysis and survey method. Through this study it is evident that slimming advertisements use print media as an effective tool to persuade the target audience.

Keywords: Slimming Products, Impact, Advertisements, Print Media, Youngsters

\section{INTRODUCTION}

Many years, advertisement plays a major role among people in creating awareness among weight loss information targeting with message to achieve their slimming body reflection. This has led to a noticeable increase in the frequency of advertisements of slimming and weight loss products. Anderson et al. (2008). Everyone dreams to have a slender and fit body, and this has become an obsession for many people in the last couple of decades. Many discoveries in the recent years have brought in many messages related to metabolizing functions of body. There have been so many products in market for slimming, weight loss like pills and some slimming products, cosmetics, surgeries, and other equipment's which promise quick ways to lose fat. Bansal et al. (2010).

Obviously, the key cause of this occurrence is the ubiquitous weight loss commercials. Many diets product selling companies use advertisements as an instrument to persuade youngsters by instilling the perception of slim is beauty in their minds. Mostly women consumers are vigorously having conscious about their slim beauty then men and this extremely tends to choose slimming products and to consume in weight loss process rather than natural food diet and exercise etc. 
Brown (2005). Hence repetitive weight loss advertisements appearing in media are exaggerated immensely to appeal to the target audience. Advertisements found in media about such products lure them to take a step ahead and try it, since this creates harmful to the body and change ahead and try it since this creates harmful to the body and change metabolic level in creating many disorders in the human body. Bordo (2003).

Lot of people, especially youngsters inclined to prefer slimming weight loss products to maintain slim beauty and blindly follow these advertisements. Frequency of the advertisements for slimming products appearing in print media is notably high. There seems to be a lot of exaggeration in the advertisements for slimming products. Lots of tricks and tactics are used by these advertisements to attract the target audience. Diaz (2011). This study would help us to understand various slimming advertisements appearing in print media and the impact created among the youngsters. Cohen (2006). Thus, the aim of this study is to analyse various advertisements related to slimming products in print media and to find out its impact among youngsters.

\subsection{OBJECTIVES}

- To find the advertisements related to slimming products in print media.

- To analyse the content of various advertisements through print media.

- To find the impact of these advertisements among youngsters.

In this context, it becomes important to study the advertisements related to slimming products and services appearing in print media. It is essential to understand the characteristics of these advertisements by analysing them. Grogan (2008). The impact created by these advertisements can also be studied to know the opinion of the target audience who are mostly youngsters and how it has affected them.

\section{RESEARCH METHODOLOGY}

Methodology adopted for this study was,

- Content Analysis

- Survey Method

\subsection{CONTENT ANALYSIS}

The main purpose of this study was to analyse Advertisements related to Slimming Products in Print media. In this study advertisements related to slimming products and services were collected from selected Newspapers and magazines for content analysis. A total of about 65 advertisements from more than 22 companies were reviewed from around 50 separate issues of different publications. These ads were individually analysed based on certain parameters. Advertisements that appeared in Newspapers and Magazines for three months of April to June 2019 and 2020 were selected for analysis.

Some of the leading Newspapers and Magazines were selected for analysing the slimming advertisements. 
- The Hindu

- Times of India

- Dhina Thanthi

- Femina

- Stardust

- Kumu dam

\subsection{SURVEY METHOD}

In this study, a Survey was used to measure the impact of slimming advertisements among youngsters. The sampling method used for this study is purposive sampling. Hence, Purposive sampling is used in this study as the respondents should have regular access to at least one of the selected publications. Also, only those respondents who said they have passion to become slim were chosen since they will look out for slimming advertisements.

Sampling specifications with regard to this research

Sample Size

: 100 respondents

Universe

: People of Age Group 18 - 30 Yrs.

\subsection{THEORETICAL PERSPECTIVE}

There are many theories have been stated and developed to elucidate dissimilar features of persuasion of various media and its influence. One such theory which is relevant to this field of study is discussed below. Cognitive response theory is an attempt to understand how people's attitude change when they look at persuasive slimming advertisements. Kapadia and Kalidas (2009). People who have the thought that they are fat, and they have to slim down are likely to have more chances of being persuaded by these advertisements. Hobbs et al. (2006).

\section{ANALYSIS AND INTERPRETATION}

The methodology adopted for the study is Content Analysis and Survey. Various slimming advertisements from print media were collected and analysed based on the given parameters. The content analysis has been divided into four categories, Food and Pharma, Physical Equipment's, Slimming Centres and Cosmetics \& Surgery. The interpretation of data is presented in table format. The results of survey to measure the impact of the advertisements among youngsters are depicted in the form of pie charts.

\subsection{CONTENT ANALYSIS}

A total of about 65 advertisements from more than 22 companies were reviewed from around 50 separate issues of different publications.

\subsubsection{PARAMETERS USED FOR CONTENT ANALYSIS} below.

The advertisements were individually analysed based on parameters given 
- Publication

- Position

- Size

- Target

- Frequency

- Message

- Visualization

- Characters

- Ethical value

- Communication objective

- Appeal

\subsubsection{ANALYSIS OF SLIMMING ADVERTISEMENTS}

\subsubsection{FOOD AND PHARMA}

\section{Table 1 Analysis of Food and Pharma Advertisements}

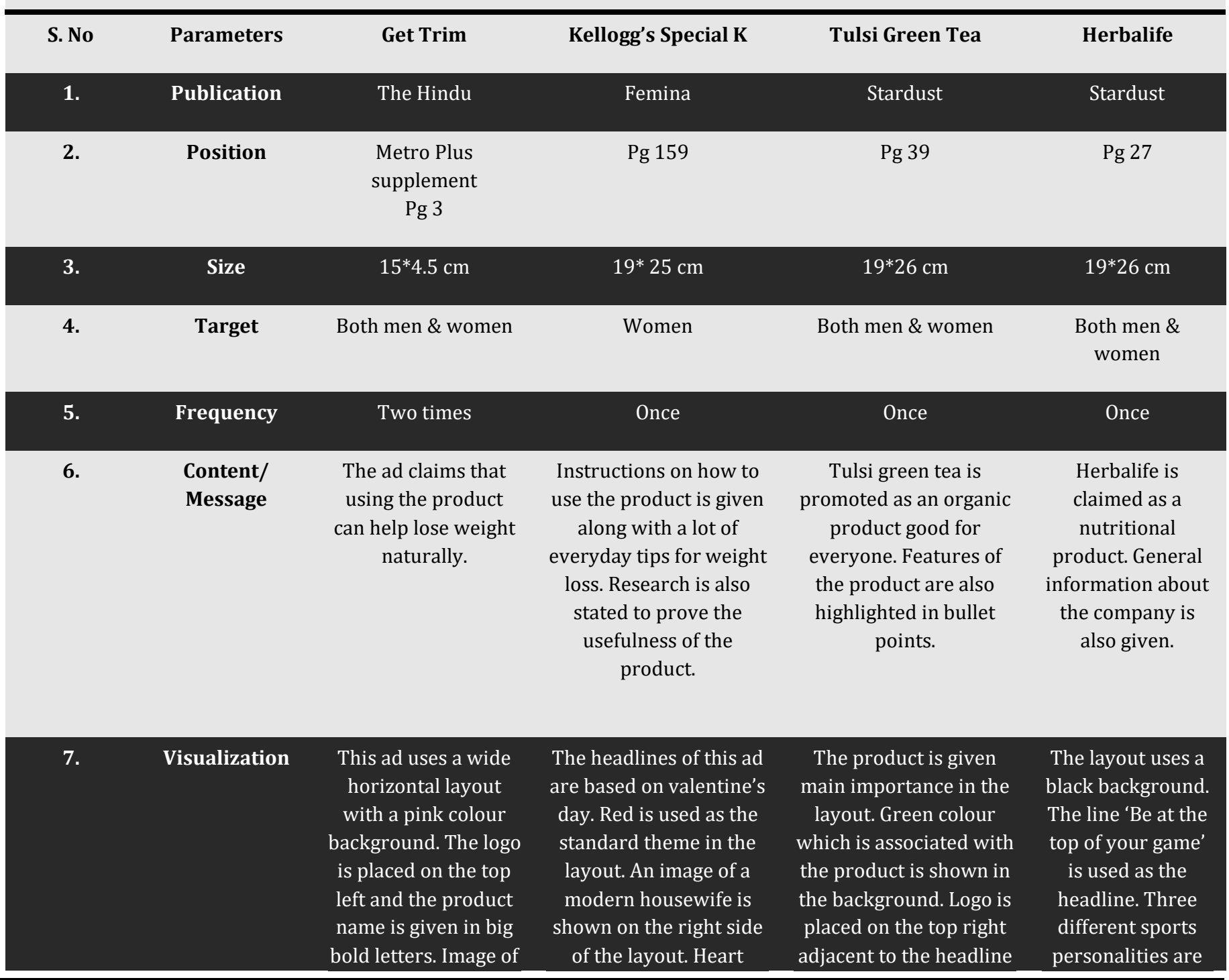


Dr. P. Sri Jothi, and Dr. A Jayanthiladevi

\begin{tabular}{|c|c|c|c|c|c|}
\hline & & $\begin{array}{c}\text { the product is given } \\
\text { on the right side of } \\
\text { the layout. }\end{array}$ & $\begin{array}{l}\text { shaped graphics are } \\
\text { used to denote } \\
\text { valentine's day. Content } \\
\text { which gives information } \\
\text { and tips are given in two } \\
\text { columns. The product is } \\
\text { also highlighted at the } \\
\text { bottom of the layout. }\end{array}$ & $\begin{array}{l}\text { stating 'Discover true } \\
\text { wellnesses. Image of the } \\
\text { product is placed in the } \\
\text { centre. Features of the } \\
\text { product are highlighted } \\
\text { in bullet points at the } \\
\text { bottom of the layout. }\end{array}$ & $\begin{array}{l}\text { seen endorsing the } \\
\text { product to attract } \\
\text { the target. Product } \\
\text { images and } \\
\text { general } \\
\text { information about } \\
\text { the company are } \\
\text { also given. }\end{array}$ \\
\hline 8. & Characters & None & $\begin{array}{l}\text { A woman of } 25-30 \text { age } \\
\text { group is shown to } \\
\text { represent a modern } \\
\text { housewife. }\end{array}$ & None & $\begin{array}{c}\text { Three different } \\
\text { sports } \\
\text { personalities } \\
\text { namely Virat Kohli, } \\
\text { Mari Kom and } \\
\text { Saina Nehwal are } \\
\text { shown. }\end{array}$ \\
\hline 9. & Ethical Value & $\begin{array}{l}\text { This ad claims we } \\
\text { can lose weight } \\
\text { naturally, but it is not } \\
\text { proved. }\end{array}$ & $\begin{array}{l}\text { No major exaggeration } \\
\text { was there. It was } \\
\text { mentioned that the } \\
\text { product is } 98 \% \text { fat free } \\
\text { which is not proved. }\end{array}$ & $\begin{array}{l}\text { This ad doesn't use any } \\
\text { unethical claims. }\end{array}$ & $\begin{array}{l}\text { This ad doesn't use } \\
\text { any unethical } \\
\text { claims. }\end{array}$ \\
\hline 10. & $\begin{array}{l}\text { Communication } \\
\text { Objective }\end{array}$ & To sell their product. & To sell their product. & To sell the product. & $\begin{array}{l}\text { To sell the } \\
\text { product. }\end{array}$ \\
\hline 11. & Appeal & Rational & Rational & Rational & $\begin{array}{l}\text { Rational, Brand, } \\
\text { Endorsement }\end{array}$ \\
\hline
\end{tabular}

\subsubsection{PHYSICAL EQUIPMENTS}

\begin{tabular}{|c|c|c|c|c|c|c|c|}
\hline S. No & $\begin{array}{c}\text { Parameters } \\
\text { meters }\end{array}$ & WellCare & Propel Fitnesss & Afton & Acme Fitnesss & $\begin{array}{l}\text { Landmark } \\
\text { Associates }\end{array}$ & Sportus \\
\hline 1 & Publication & Times Of India & Times Of India & Times Of India & The Hindu & The Hindu & Daily Thanthi \\
\hline 2 & Position & $\begin{array}{c}\text { Chennai Times } \\
\text { supplement Pg } \\
18\end{array}$ & $\begin{array}{c}\text { Chennai Times } \\
\text { supplement Pg } \\
18\end{array}$ & $\begin{array}{c}\text { Times of India } \\
\text { Pg } 6\end{array}$ & $\begin{array}{c}\text { Metro Plus } \\
\text { supplement Pg } \\
13\end{array}$ & The Hindu Pg 6 & Pg 27 \\
\hline 3 & Size & $6^{*} 10 \mathrm{~cm}$ & $6 * 10 \mathrm{~cm}$ & $6 * 10 \mathrm{~cm}$ & $8^{*} 10 \mathrm{~cm}$ & $4 * 9 \mathrm{~cm}$ & $8 * 4 \mathrm{~cm}$ \\
\hline 4 & Target & $\begin{array}{l}\text { Both men \& } \\
\text { women }\end{array}$ & Women & Women & $\begin{array}{l}\text { Both men \& } \\
\text { women }\end{array}$ & Men & $\begin{array}{l}\text { Both men \& } \\
\text { women }\end{array}$ \\
\hline 5 & Frequency & Four times & Four times & Three times & Once & Four times & Four times \\
\hline 6 & $\begin{array}{l}\text { Content/ } \\
\text { Message }\end{array}$ & $\begin{array}{l}\text { Features about } \\
\text { the products } \\
\text { and services } \\
\text { are listed in } \\
\text { bullet points. }\end{array}$ & $\begin{array}{l}\text { Features about } \\
\text { the products and } \\
\text { services are } \\
\text { listed in bullet } \\
\text { points. }\end{array}$ & $\begin{array}{l}\text { It carries a } \\
\text { message that } \\
\text { they sell } \\
\text { treadmills, and } \\
\text { other physical } \\
\text { equipment's. }\end{array}$ & $\begin{array}{l}\text { Product } \\
\text { description is } \\
\text { given. }\end{array}$ & $\begin{array}{l}\text { Information } \\
\text { about the } \\
\text { products is } \\
\text { given. }\end{array}$ & $\begin{array}{l}\text { It says the } \\
\text { company deals } \\
\text { with sales and } \\
\text { service of } \\
\text { physical } \\
\text { equipment's. }\end{array}$ \\
\hline
\end{tabular}


A Study on the Advertisements Related to Slimming Products in Print Media and Its Impact Among Youngsters

\begin{tabular}{|c|c|c|c|c|c|c|c|}
\hline 7 & $\begin{array}{c}\text { Visualizatio } \\
\text { n }\end{array}$ & $\begin{array}{l}\text { The logo is } \\
\text { given on the } \\
\text { top right } \\
\text { followed by a } \\
\text { slogan. The } \\
\text { words 'Trusted } \\
\text { brand' is } \\
\text { highlighted in } \\
\text { bold text. An } \\
\text { image of } \\
\text { physical } \\
\text { equipment is } \\
\text { shown. } \\
\text { Features about } \\
\text { the product are } \\
\text { highlighted in } \\
\text { bullet points. }\end{array}$ & $\begin{array}{l}\text { The logo is } \\
\text { placed on the top } \\
\text { right. The offer is } \\
\text { highlighted with } \\
\text { bold letters of } \\
\text { white text in a } \\
\text { blue strip } \\
\text { represented } \\
\text { diagonally. An } \\
\text { image of a } \\
\text { woman and } \\
\text { physical } \\
\text { equipment is } \\
\text { shown. Cost of } \\
\text { the product is } \\
\text { highlighted in } \\
\text { bold white text } \\
\text { in an orange } \\
\text { dialogue box. } \\
\text { Features about } \\
\text { the product are } \\
\text { highlighted in } \\
\text { bullet points } \\
\text { followed by } \\
\text { contact details. }\end{array}$ & $\begin{array}{c}\text { A strong } \\
\text { headline is } \\
\text { used with bold } \\
\text { text. Yellow } \\
\text { and red are the } \\
\text { mail colors } \\
\text { used. Four } \\
\text { different brand } \\
\text { logos are used } \\
\text { followed by } \\
\text { two images of } \\
\text { women using } \\
\text { physical } \\
\text { equipment's. } \\
\text { Products are } \\
\text { highlighted in } \\
\text { bullet points. }\end{array}$ & $\begin{array}{l}\text { The words } \\
\text { 'Delete Stress' } \\
\text { highlighted in } \\
\text { red with big } \\
\text { and bold } \\
\text { letters } \\
\text { occupies the } \\
\text { first half of the } \\
\text { layout. Three } \\
\text { different } \\
\text { images of the } \\
\text { products are } \\
\text { shown in the } \\
\text { center. } \\
\text { Gradient is } \\
\text { used in the } \\
\text { background. }\end{array}$ & $\begin{array}{l}\text { The ad has a } \\
\text { very simple } \\
\text { layout with } \\
\text { yellow as its } \\
\text { theme color. A } \\
\text { cropped image } \\
\text { of a man with } \\
\text { six packs is } \\
\text { shown in the } \\
\text { center along } \\
\text { with an image } \\
\text { of the } \\
\text { equipment } \\
\text { followed by the } \\
\text { logo. The } \\
\text { words 'world } \\
\text { class brands' is } \\
\text { heighted in } \\
\text { blue color. }\end{array}$ & $\begin{array}{l}\text { It uses a simple } \\
\text { layout of red } \\
\text { background. } \\
\text { The company } \\
\text { name is given } \\
\text { on top } \\
\text { followed by an } \\
\text { image of a } \\
\text { woman and } \\
\text { description of } \\
\text { their products. }\end{array}$ \\
\hline 8 & Characters & None & $\begin{array}{l}\text { A woman } \\
\text { representing a } \\
\text { housewife of the } \\
\text { age group } 25 \text { - } \\
30 \text { is shown. }\end{array}$ & $\begin{array}{l}\text { Two women of } \\
\text { the age group } \\
20-25 \\
\text { working on } \\
\text { physical } \\
\text { equipment's } \\
\text { are shown. }\end{array}$ & $\begin{array}{l}\text { Two women } \\
\text { representing } \\
\text { athletes are } \\
\text { shown. }\end{array}$ & $\begin{array}{l}\text { Cropped photo } \\
\text { focusing the } \\
\text { body of a } \\
\text { muscular man } \\
\text { with six packs } \\
\text { is shown in this } \\
\text { ad. }\end{array}$ & $\begin{array}{l}\text { A woman of } 20 \\
-25 \text { age group } \\
\text { working on a } \\
\text { physical } \\
\text { equipment is } \\
\text { shown. }\end{array}$ \\
\hline 9 & $\begin{array}{l}\text { Ethical } \\
\text { Value }\end{array}$ & $\begin{array}{l}\text { No unethical } \\
\text { claims are used } \\
\text { in this ad. }\end{array}$ & $\begin{array}{l}\text { No unethical } \\
\text { claims are used } \\
\text { in this ad. }\end{array}$ & $\begin{array}{l}\text { No unethical } \\
\text { claims are used } \\
\text { in this ad. }\end{array}$ & $\begin{array}{l}\text { No unethical } \\
\text { claims are } \\
\text { used. }\end{array}$ & $\begin{array}{c}\text { It uses an } \\
\text { unethical claim } \\
\text { stating, 'Lose } 5 \\
\text { kgs in } 5 \text { days.' } \\
\text { And } \\
\text { exaggerated } \\
\text { content. }\end{array}$ & $\begin{array}{l}\text { This ad doesn't } \\
\text { use any } \\
\text { unethical } \\
\text { claims. }\end{array}$ \\
\hline 10 & $\begin{array}{c}\text { Communicat } \\
\text { ion } \\
\text { Objective }\end{array}$ & $\begin{array}{l}\text { To sell fitness } \\
\text { equipment's. }\end{array}$ & $\begin{array}{l}\text { To sell fitness } \\
\text { equipment's. }\end{array}$ & $\begin{array}{l}\text { To sell fitness } \\
\text { equipment's. }\end{array}$ & $\begin{array}{l}\text { To sell fitness } \\
\text { equipment's. }\end{array}$ & $\begin{array}{l}\text { To sell fitness } \\
\text { equipment's. }\end{array}$ & $\begin{array}{l}\text { To sell their } \\
\text { products. }\end{array}$ \\
\hline 11 & Appeal & Rational, Brand & Rational & Rational & Rational & Rational & Rational \\
\hline
\end{tabular}

\subsubsection{SLIMMING CENTRES}

Table 3 Analysis of Slimming Centre Advertisements

\begin{tabular}{|c|c|c|c|c|c|c|c|c|c|}
\hline S. No & Parameters & VLCC (a) & VLCC (b) & La Belle & Ayushman & Dr. Nigam & $\begin{array}{l}\text { O2 Health } \\
\text { studio }\end{array}$ & $\begin{array}{c}\text { Fitness } \\
\text { One }\end{array}$ & Kolors \\
\hline 1. & Publication & $\begin{array}{c}\text { Times of } \\
\text { India }\end{array}$ & $\begin{array}{c}\text { Times of } \\
\text { India }\end{array}$ & $\begin{array}{c}\text { Slimming } \\
\text { centre }\end{array}$ & $\begin{array}{c}\text { Times Of } \\
\text { India }\end{array}$ & $\begin{array}{c}\text { Times Of } \\
\text { India }\end{array}$ & $\begin{array}{c}\text { Times Of } \\
\text { India }\end{array}$ & $\begin{array}{c}\text { The } \\
\text { Hindu }\end{array}$ & $\begin{array}{l}\text { Daily } \\
\text { Thanthi }\end{array}$ \\
\hline
\end{tabular}


Dr. P. Sri Jothi, and Dr. A Jayanthiladevi

\begin{tabular}{|c|c|c|c|c|c|c|c|c|c|}
\hline 2. & Position & $\begin{array}{l}\text { Chennai } \\
\text { Times } \\
\text { suppleme } \\
\text { nt Pg } 1\end{array}$ & $\begin{array}{l}\text { Chennai } \\
\text { Times } \\
\text { supplement } \\
\text { Pg } 1\end{array}$ & $\begin{array}{l}\text { Cinema } \\
\text { Plus } \\
\text { suppleme } \\
\text { nt } \\
\text { Pg } 1\end{array}$ & $\begin{array}{l}\text { Chennai } \\
\text { Times } \\
\text { supplement } \\
\text { Pg } 18\end{array}$ & $\begin{array}{c}\text { Times of } \\
\text { India Pg } 6\end{array}$ & $\begin{array}{l}\text { Chennai } \\
\text { Times } \\
\text { supplement } \\
\text { Pg } 10\end{array}$ & $\begin{array}{c}\text { Metro } \\
\text { Plus } \\
\text { suppleme } \\
\text { nt Pg } 13\end{array}$ & $\begin{array}{l}\text { Daily } \\
\text { Thanthi } \\
\text { Pg } 25\end{array}$ \\
\hline 3. & Size & $12 * 20 \mathrm{~cm}$ & $12 * 20 \mathrm{~cm}$ & $8 * 20 \mathrm{~cm}$ & $6^{*} 10 \mathrm{~cm}$ & $3 * 12 \mathrm{~cm}$ & $8 * 10 \mathrm{~cm}$ & $4 * 20 \mathrm{~cm}$ & $\begin{array}{l}3.5^{*} 6 \\
\mathrm{~cm}\end{array}$ \\
\hline 4. & Target & Women & $\begin{array}{c}\text { Both men \& } \\
\text { women }\end{array}$ & Women & $\begin{array}{l}\text { Both men \& } \\
\text { women }\end{array}$ & Men & $\begin{array}{l}\text { Both men \& } \\
\text { women }\end{array}$ & $\begin{array}{l}\text { Both men } \\
\text { \& women }\end{array}$ & $\begin{array}{l}\text { Both } \\
\text { men \& } \\
\text { women }\end{array}$ \\
\hline 5. & Frequency & $\begin{array}{l}\text { Four } \\
\text { times }\end{array}$ & Four times & $\begin{array}{l}\text { Two } \\
\text { times }\end{array}$ & Four times & Two times & $\begin{array}{l}\text { Three } \\
\text { times }\end{array}$ & $\begin{array}{l}\text { Two } \\
\text { times }\end{array}$ & $\begin{array}{l}\text { Five } \\
\text { times }\end{array}$ \\
\hline 6. & $\begin{array}{l}\text { Content/ } \\
\text { Message }\end{array}$ & $\begin{array}{l}\text { A new } \\
\text { program } \\
\text { called } \\
\text { 'Turbosli } \\
\text { m' is } \\
\text { introduce } \\
\text { d with an } \\
\text { offer of } \\
\text { free } \\
\text { additiona } \\
\text { l weight } \\
\text { loss up to } \\
5 \text { kgs. }\end{array}$ & $\begin{array}{l}\text { A limited } \\
\text { offer is } \\
\text { introduced } \\
\text { with } 30 \% \\
\text { discount on } \\
\text { all } \\
\text { slimming } \\
\text { and beauty } \\
\text { packages. }\end{array}$ & $\begin{array}{l}\text { Customer } \\
\text { testimony } \\
\text { is the } \\
\text { main } \\
\text { content } \\
\text { along } \\
\text { with a } \\
\text { fantasy } \\
\text { offers. }\end{array}$ & $\begin{array}{l}\text { Information } \\
\text { and features } \\
\text { about the } \\
\text { products and } \\
\text { services are } \\
\text { given along } \\
\text { with offers. }\end{array}$ & $\begin{array}{l}\text { It claims that } \\
\text { we can lose } \\
20 \mathrm{~kg} \text { by } 15^{\text {th }} \\
\text { May. }\end{array}$ & $\begin{array}{c}\text { It } \\
\text { introduces } \\
\text { special } \\
\text { offer for } \\
\text { valentine's } \\
\text { day with } \\
\text { free } \\
\text { membershi } \\
\text { p and gifts. }\end{array}$ & $\begin{array}{l}\text { Words of } \\
\text { Charles } \\
\text { Dickens } \\
\text { are } \\
\text { quoted, } \\
\text { and } \\
\text { Valentine' } \\
\text { s Day } \\
\text { offer is } \\
\text { described } \\
\text { in the } \\
\text { copy. }\end{array}$ & $\begin{array}{l}\text { Feature } \\
\mathrm{s} \quad \text { of } \\
\text { their } \\
\text { service } \\
\text { are } \\
\text { given. It } \\
\text { says } \\
\text { one can } \\
\text { lose up } \\
\text { to } 6 \\
\text { inches } \\
\text { in } 60 \\
\text { minute } \\
\mathrm{s} \text { with a } \\
\text { flat } \\
25 \% \\
\text { discoun } \\
\mathrm{t} \text { and } \\
\text { other } \\
\text { service } \\
\mathrm{s} \text {. }\end{array}$ \\
\hline 7. & $\begin{array}{c}\text { Visualizatio } \\
\mathbf{n}\end{array}$ & $\begin{array}{l}\text { In this } \\
\text { layout a } \\
\text { headline } \\
\text { is used } \\
\text { with bold } \\
\text { letters of } \\
\text { white text } \\
\text { in blue } \\
\text { backgrou } \\
\text { nd. The } \\
\text { word } \\
\text { 'Turbosli } \\
\text { m' is } \\
\text { highlighte } \\
\text { d in red. } \\
\text { A single } \\
\text { image is }\end{array}$ & $\begin{array}{l}\text { A headline } \\
\text { is used } \\
\text { with bold } \\
\text { letters of } \\
\text { white text } \\
\text { in blue } \\
\text { backgroun } \\
\text { d. Two } \\
\text { images are } \\
\text { shown } \\
\text { holding } \\
\text { messages. } \\
\text { Discount } \\
\text { offer is } \\
\text { highlighted } \\
\text { in a blue } \\
\text { box. }\end{array}$ & $\begin{array}{l}\text { The } \\
\text { headline } \\
\text { of this ad } \\
\text { is based } \\
\text { on before } \\
\text { and after } \\
\text { images. } \\
\text { Two } \\
\text { images of } \\
\text { the same } \\
\text { character } \\
\text { are used } \\
\text { to show } \\
\text { the } \\
\text { differenc } \\
\text { e in body } \\
\text { weight. It }\end{array}$ & $\begin{array}{l}\text { The ad layout } \\
\text { is very } \\
\text { simple with } \\
\text { green as its } \\
\text { theme colour. } \\
\text { The logo is } \\
\text { given on the } \\
\text { top followed } \\
\text { by a bold } \\
\text { caption. Offer } \\
\text { and claims } \\
\text { are } \\
\text { highlighted } \\
\text { in a yellow } \\
\text { background. } \\
\text { Information } \\
\text { about }\end{array}$ & $\begin{array}{l}\text { This ad is } \\
\text { given in a } \\
\text { vertical } \\
\text { layout. Green } \\
\text { is the theme } \\
\text { colour used } \\
\text { for this ad. } \\
\text { Hair } \\
\text { transplant } \\
\text { and weight } \\
\text { loss } \\
\text { messages are } \\
\text { highlighted } \\
\text { in yellow } \\
\text { text. }\end{array}$ & $\begin{array}{l}\text { The logo is } \\
\text { given on } \\
\text { the top left. } \\
\text { Headline is } \\
\text { given in } \\
\text { pink colour } \\
\text { to denote } \\
\text { valentine's } \\
\text { day. Offer is } \\
\text { given in a } \\
\text { small font } \\
\text { followed by } \\
\text { an image of } \\
\text { apple with } \\
\text { heart } \\
\text { etched in it } \\
\text { which }\end{array}$ & $\begin{array}{l}\text { This ad } \\
\text { uses a } \\
\text { vertical } \\
\text { layout } \\
\text { and is } \\
\text { based on } \\
\text { valentine' } \\
\text { s day } \\
\text { theme. } \\
\text { The top } \\
\text { of the } \\
\text { layout } \\
\text { consists } \\
\text { of a quote } \\
\text { followed } \\
\text { by an } \\
\text { illustratio }\end{array}$ & $\begin{array}{l}\text { The } \\
\text { words } \\
\text { 'Lose } \\
\text { up to } 6 \\
\text { inches } \\
\text { in } 60 \\
\text { minute } \\
\mathrm{s} \text { ' is } \\
\text { highlig } \\
\text { hted in } \\
\text { red, } \\
\text { followe } \\
d \\
\text { discoun by } \\
t \\
\text { highlig } \\
\text { hted in }\end{array}$ \\
\hline
\end{tabular}


A Study on the Advertisements Related to Slimming Products in Print Media and Its Impact Among Youngsters

\begin{tabular}{|c|c|c|c|c|c|c|c|c|c|}
\hline & & $\begin{array}{l}\text { shown on } \\
\text { the right } \\
\text { side of } \\
\text { the } \\
\text { layout. } \\
\text { Introduct } \\
\text { ory offer } \\
\text { is } \\
\text { highlighte } \\
\text { d } \\
\text { followed } \\
\text { by the } \\
\text { text } \\
\text { describin } \\
\text { g } \\
\text { turboslim } \\
\text {, } \\
\text { company } \\
\text { logo and } \\
\text { contact } \\
\text { address. }\end{array}$ & $\begin{array}{l}\text { Description } \\
\text { of services, } \\
\text { company } \\
\text { logo and } \\
\text { address are } \\
\text { given in the } \\
\text { bottom of } \\
\text { the layout. }\end{array}$ & $\begin{array}{c}\text { is } \\
\text { followed } \\
\text { by a } \\
\text { testimony } \\
\text { given by } \\
\text { the } \\
\text { character. } \\
\text { Fantasy } \\
\text { offers are } \\
\text { highlighte } \\
\text { d } \\
\text { followed } \\
\text { by the } \\
\text { logo and } \\
\text { contact } \\
\text { details. }\end{array}$ & $\begin{array}{l}\text { products and } \\
\text { services are } \\
\text { also given. }\end{array}$ & & $\begin{array}{c}\text { represents } \\
\text { romance. }\end{array}$ & $\begin{array}{c}\text { n of a } \\
\text { couple } \\
\text { running } \\
\text { together } \\
\text { in a heart } \\
\text { shaped } \\
\text { backgrou } \\
\text { nd. The } \\
\text { word } \\
\text { 'Fitness } \\
\text { together' } \\
\text { is } \\
\text { highlighte } \\
\text { d in a } \\
\text { dark } \\
\text { purple } \\
\text { backgrou } \\
\text { nd. The } \\
\text { other half } \\
\text { of the } \\
\text { layout } \\
\text { contains } \\
\text { the main } \\
\text { copy. }\end{array}$ & $\begin{array}{l}\text { yellow. } \\
\text { An } \\
\text { image } \\
\text { of a } \\
\text { woman } \\
\text { is } \\
\text { shown } \\
\text { on the } \\
\text { right } \\
\text { side of } \\
\text { the } \\
\text { layout. }\end{array}$ \\
\hline 8. & Characters & $\begin{array}{c}\text { A } \\
\text { stereotyp } \\
\text { ical } \\
\text { college } \\
\text { going girl } \\
\text { of } 18-20 \\
\text { age group } \\
\text { is shown. }\end{array}$ & $\begin{array}{l}\text { Male and } \\
\text { female } \\
\text { foreigners } \\
\text { are } \\
\text { represente } \\
\text { d for } \\
\text { internation } \\
\text { al } \\
\text { reputation. }\end{array}$ & $\begin{array}{l}\text { A woman } \\
\text { of } 20-25 \\
\text { age group } \\
\text { is used in } \\
\text { the } \\
\text { before } \\
\text { and after } \\
\text { images. }\end{array}$ & None & $\begin{array}{c}\text { A bald } \\
\text { headed and } \\
\text { extremely fat } \\
\text { man of age } \\
\text { group } 30- \\
35 \text { is shown. }\end{array}$ & None & $\begin{array}{l}\text { Illustratio } \\
\mathrm{n} \text { of a } \\
\text { couple } \\
\text { running } \\
\text { together. }\end{array}$ & $\begin{array}{l}\text { A } \\
\text { croppe } \\
\mathrm{d} \text { image } \\
\text { focusin } \\
\mathrm{g} \text { the } \\
\text { hip size } \\
\text { of a } \\
\text { woman } \\
\text { of } 18 \text { - } \\
20 \text { age } \\
\text { group is } \\
\text { shown. }\end{array}$ \\
\hline 9. & $\begin{array}{c}\text { Ethical } \\
\text { Value }\end{array}$ & $\begin{array}{l}\text { The ad } \\
\text { uses } \\
\text { unethical } \\
\text { claim } \\
\text { stating, } \\
\text { 'we help } \\
\text { you lose } \\
\text { extra cms } \\
\text { faster.' }\end{array}$ & $\begin{array}{c}\text { No } \\
\text { unethical } \\
\text { claims are } \\
\text { used in this } \\
\text { ad. }\end{array}$ & $\begin{array}{l}\text { The } \\
\text { before } \\
\text { and after } \\
\text { images } \\
\text { used in } \\
\text { this ad } \\
\text { are } \\
\text { exaggerat } \\
\text { ed. }\end{array}$ & $\begin{array}{l}\text { It uses an } \\
\text { unethical } \\
\text { claim stating, } \\
\text { 'Lose } 5 \text { kgs in } \\
5 \text { days.' And } \\
\text { exaggerated } \\
\text { content. }\end{array}$ & $\begin{array}{c}\text { The ad is } \\
\text { exaggerated, } \\
\text { and it uses an } \\
\text { unethical } \\
\text { claim stating } \\
\text { 'Lose } 20 \mathrm{~kg} \text { by } \\
15^{\text {th }} \text { May' }\end{array}$ & $\begin{array}{c}\text { No } \\
\text { unethical } \\
\text { claims are } \\
\text { used in this } \\
\text { ad. }\end{array}$ & $\begin{array}{l}\text { No } \\
\text { unethical } \\
\text { claims } \\
\text { are used } \\
\text { in this ad. }\end{array}$ & $\begin{array}{l}\text { It uses } \\
\text { an } \\
\text { unethic } \\
\text { al claim } \\
\text { stating } \\
\text { lose } 6 \\
\text { inches } \\
\text { in } 60 \\
\text { minute } \\
\text { s. }\end{array}$ \\
\hline 10. & $\begin{array}{c}\text { Communicat } \\
\text { ion } \\
\text { Objective }\end{array}$ & $\begin{array}{l}\text { To make } \\
\text { men and } \\
\text { women } \\
\text { join their } \\
\text { centre. }\end{array}$ & $\begin{array}{c}\text { To make } \\
\text { men and } \\
\text { women join } \\
\text { their } \\
\text { centre. }\end{array}$ & $\begin{array}{l}\text { To make } \\
\text { women } \\
\text { join their } \\
\text { centre. }\end{array}$ & $\begin{array}{l}\text { To make men } \\
\text { and women } \\
\text { join their } \\
\text { centre. }\end{array}$ & $\begin{array}{l}\text { To make men } \\
\text { and women } \\
\text { join their } \\
\text { centre. }\end{array}$ & $\begin{array}{c}\text { To make } \\
\text { men and } \\
\text { women join } \\
\text { their } \\
\text { centre. }\end{array}$ & $\begin{array}{l}\text { To make } \\
\text { women } \\
\text { join their } \\
\text { centre. }\end{array}$ & $\begin{array}{l}\text { To } \\
\text { promot } \\
\text { e their } \\
\text { service } \\
\text { s. }\end{array}$ \\
\hline
\end{tabular}


Dr. P. Sri Jothi, and Dr. A Jayanthiladevi

\begin{tabular}{|c|c|c|c|c|c|c|c|c|c|}
\hline 11. & Appeal & Rational & $\begin{array}{c}\text { Fear, } \\
\text { Scarcity }\end{array}$ & $\begin{array}{c}\text { Personal, } \\
\text { scarcity }\end{array}$ & Rational & Fear, rational & $\begin{array}{l}\text { Personal, } \\
\text { romance, } \\
\text { scarcity }\end{array}$ & Romance & $\begin{array}{l}\text { Rationa } \\
\text { l }\end{array}$ \\
\hline
\end{tabular}

\subsubsection{SURGERY AND COSMETICS}

\section{Table 4 Analysis of Surgery and Cosmetics Advertisements}

\begin{tabular}{|c|c|c|c|c|c|c|}
\hline S. No & Parameters & $\begin{array}{c}\text { Asian } \\
\text { Bariatrics }\end{array}$ & INXS & GVG Aesthetic & Angels Clinic & $\begin{array}{c}\text { Hande Medical } \\
\text { Centre }\end{array}$ \\
\hline
\end{tabular}

\begin{tabular}{|c|c|c|c|c|c|c|}
\hline 1. & Publication & Femina & Femina & Femina & Kumudam & Kumudam \\
\hline 2. & Position & Pg 175 & Pg 239 & $\operatorname{Pg} 281$ & Pg 39 & Pg 95 \\
\hline 3. & Size & $19 * 25 \mathrm{~cm}$ & $19 * 25 \mathrm{~cm}$ & $19 * 25 \mathrm{~cm}$ & $12 * 17 \mathrm{~cm}$ & $12 * 8 \mathrm{~cm}$ \\
\hline 4. & Target & $\begin{array}{l}\text { Both men \& } \\
\text { women }\end{array}$ & Women & $\begin{array}{l}\text { Both men \& } \\
\text { women }\end{array}$ & $\begin{array}{l}\text { Both men \& } \\
\text { women }\end{array}$ & Men \\
\hline 5. & Frequency & Once & Once & Once & Four times & Once \\
\hline 6. & $\begin{array}{l}\text { Content/ } \\
\text { Message }\end{array}$ & $\begin{array}{c}\text { This ad } \\
\text { introduces a } \\
\text { scarless } \\
\text { surgery. It } \\
\text { describes } \\
\text { about a weight } \\
\text { loss surgery } \\
\text { for obese } \\
\text { people } \\
\text { without a } \\
\text { single scar. }\end{array}$ & $\begin{array}{l}\text { The ad describes } \\
\text { about the latest } \\
\text { technology in } \\
\text { slimming } \\
\text { treatment called } \\
\text { 'Lipocryo'. }\end{array}$ & $\begin{array}{l}\text { Information and } \\
\text { features of } \\
\text { different health } \\
\text { services are } \\
\text { highlighted in } \\
\text { bullet points. }\end{array}$ & $\begin{array}{l}\text { Content about } \\
\text { their services } \\
\text { which include hair } \\
\text { fall treatment, } \\
\text { silicon system, } \\
\text { weight } \\
\text { management } \\
\text { program, laser } \\
\text { treatment etc. are } \\
\text { given. }\end{array}$ & $\begin{array}{l}\text { It focuses on the } \\
\text { 'Department of } \\
\text { cosmetic surgery'. } \\
\text { Description of a } \\
\text { tummy tuck surgery } \\
\text { known as } \\
\text { 'Abdominoplasty' is } \\
\text { given. }\end{array}$ \\
\hline 7. & Visualization & $\begin{array}{l}\text { This ad uses } \\
\text { orange as its } \\
\text { theme color. } \\
\text { The words } \\
\text { 'Scarless } \\
\text { surgery' is } \\
\text { used as the } \\
\text { headline. Logo } \\
\text { is placed on } \\
\text { the top right } \\
\text { side. Two } \\
\text { images of the } \\
\text { same } \\
\text { character are } \\
\text { represented to } \\
\text { show the }\end{array}$ & $\begin{array}{l}\text { The layout is } \\
\text { simple and neat } \\
\text { with lot of blank } \\
\text { space. Bright } \\
\text { yellow gradient is } \\
\text { used as the } \\
\text { background color. } \\
\text { The term 'Lipocryo' } \\
\text { is highlighted in } \\
\text { the headline. } \\
\text { Features and } \\
\text { information about } \\
\text { the services are } \\
\text { mentioned in the } \\
\text { copy. An image of a } \\
\text { slim model is }\end{array}$ & $\begin{array}{l}\text { The layout is very } \\
\text { complicated. } \\
\text { Black color is } \\
\text { used as the } \\
\text { background. } \\
\text { Helpline no. is } \\
\text { highlighted in a } \\
\text { red floral graphic. } \\
\text { The sentence 'Gift } \\
\text { you to yourself' is } \\
\text { used as the } \\
\text { headline. An } \\
\text { image focusing a } \\
\text { female hip is } \\
\text { shown to } \\
\text { represent the fit }\end{array}$ & $\begin{array}{c}\text { Two colors } \\
\text { namely pink and } \\
\text { yellow are used as } \\
\text { the theme color } \\
\text { for this layout. The } \\
\text { layout is } \\
\text { complicated with } \\
\text { lots of images and } \\
\text { content. Four } \\
\text { different services } \\
\text { are given } \\
\text { supported with } \\
\text { images. 'Get rid of } \\
\text { hair fall and } \\
\text { dandruff' is } \\
\text { highlighted below }\end{array}$ & $\begin{array}{l}\text { It has a two-column } \\
\text { layout with content } \\
\text { on one side and } \\
\text { images on the other. } \\
\text { Red and black text is } \\
\text { used in a blue } \\
\text { background. Company } \\
\text { logo and details are } \\
\text { given on the top } \\
\text { followed by the two- } \\
\text { column content and } \\
\text { images. }\end{array}$ \\
\hline
\end{tabular}


A Study on the Advertisements Related to Slimming Products in Print Media and Its Impact Among Youngsters

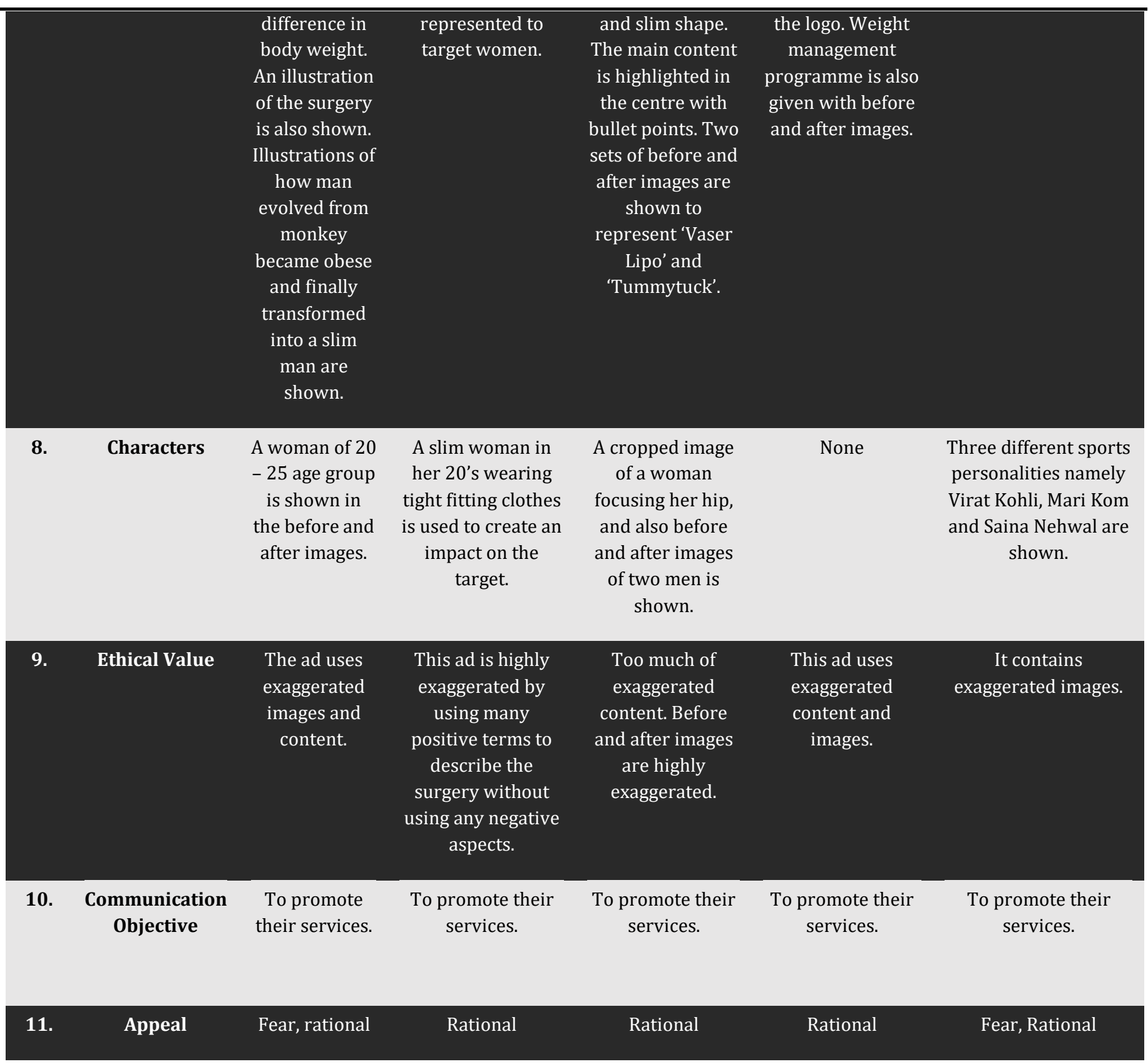

\subsection{ANALYSIS OF SURVEY}

In the survey method, around 100 samples answered the questionnaire, and their individual opinions were collected. Samples included both men and women of 18 - 30 age group, so there is no discrimination in the gender category. 


\subsubsection{MEDIA THAT HAS FREQUENT SLIMMING ADVERTISEMENTS}

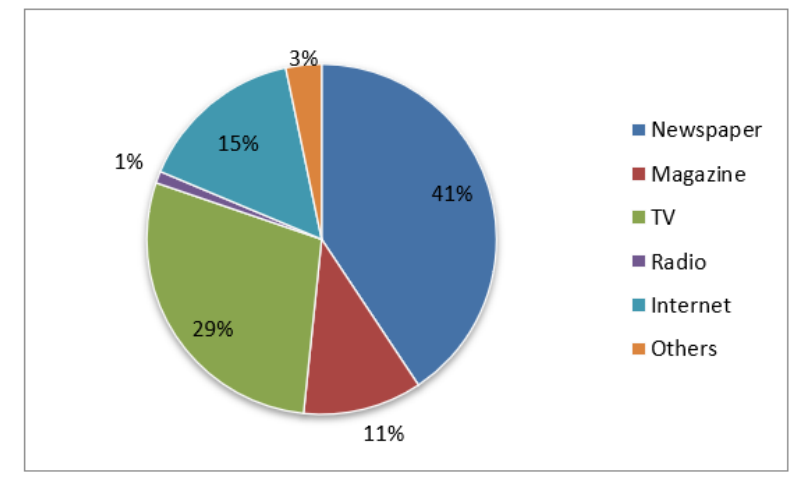

Figure 1 Media that has frequent Slimming Advertisements

This data reveals that nearly half the number of respondents felt that print media has more frequency of slimming advertisements particularly $41 \%$ said newspaper and $11 \%$ said magazine. Television was chosen by $29 \%$ of the respondents. Few respondents chose internet, and a very few chose other medium like mobile and outdoor media.

\subsubsection{PUBLICATION THAT HAS FREQUENT SLIMMING ADVERTISEMENTS}

Most of the respondents chose print and also clearly stated that the Hindu and Times of India has more frequency of slimming advertisements while a few mentioned Fermina, Kumu dam, Daily Thanthi and other publications. This clearly shows that regional newspapers like the Hindu and Times of India carry a greater number of slimming advertisements.

\subsubsection{AVERAGE NUMBER OF SLIMMING ADVERTISEMENTS FOUND EVERYDAY}

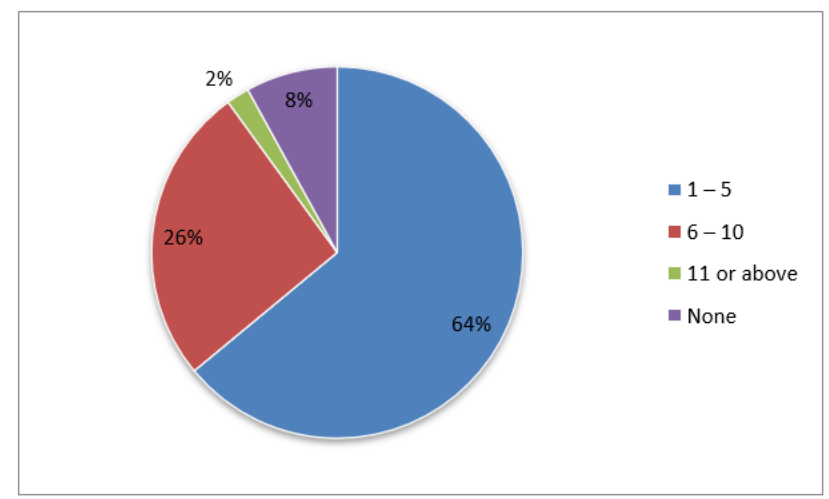

Figure 2 Average number of slimming advertisements found everyday 
Out of the total respondents, $67 \%$ revealed that on an average they approximately find less than 5 slimming advertisements every day and 31\% said 6 to 10 advertisements. Very few said they find more than 10 advertisements. This data shows that there is a probability of people to encounter at least one slimming advertisement on an average day.

\subsubsection{THE PRODUCTS THAT THEY COULD RECALL IMMEDIATELY}

Since this is an open-ended question, it is not calculated in percentage. Most of the respondents said they could recall VLCC Slimming and fitness centre easily, while a few respondents said Sauna Belt and Orbitrek equipment's which are famous in TV channels. Products like Kellogg's special slim, Herbalife nutrition and fitness drink, Dr Tea, WellCare were also mentioned by a few. All the abovementioned brands were frequently advertised in print media. This shows that people do remember various slimming advertisements from different medium. Munshi (2001).

\subsubsection{MEDIA BEST SUITED FOR SLIMMING ADVERTISEMENTS}

This question was used to find which media could be the best suited for slimming advertisements. Most of the respondents chose more than one medium since it was an open-ended question. More than half of the respondents answered this question with print media that includes newspapers and magazines. This was closely followed by television with approximately half of the respondents choosing it. Leon and Kanuk (2004). A few respondents said internet, and a very few mentioned mobile and outdoor media. This data reveals that many people expect more slimming advertisements in print media.

\subsubsection{WHETHER THEY ARE INFLUENCED BY SLIMMING ADVERTISEMENTS}

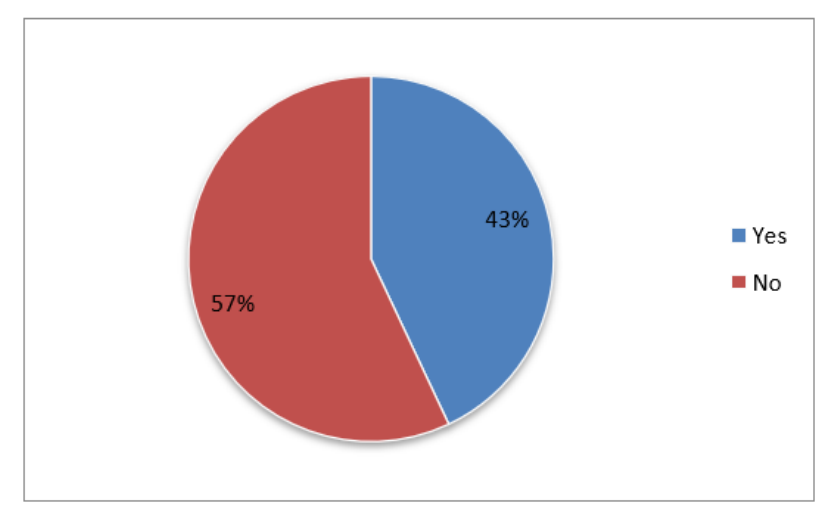

Figure 3 Whether they are influenced by Slimming Advertisements 
This question was to find out whether the slimming advertisements really influence the people. $57 \%$ of the respondents may not be influenced, but it has definitely created an impact on them. The rest $43 \%$ were clearly seemed to be influenced. This shows that people influenced by the slimming advertisements are not less in number.

\subsubsection{HOW THEY FEEL ON SEEING SLIMMING ADVERTISEMENTS}

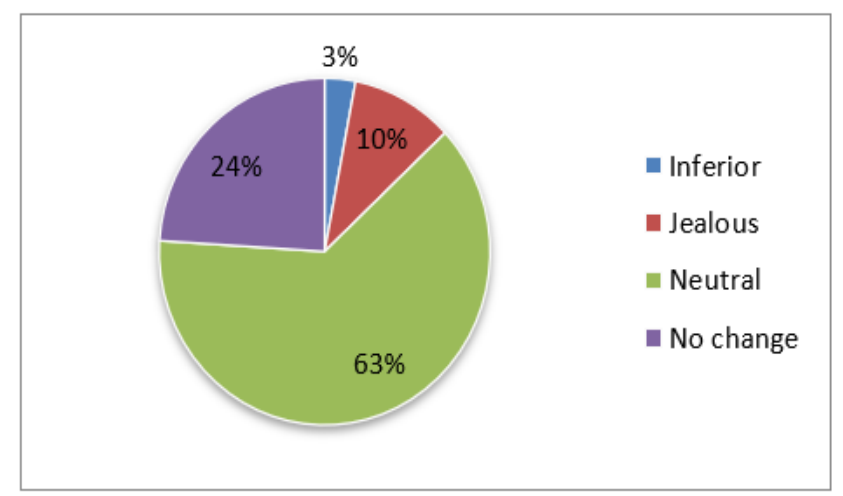

Figure 4 How they feel on seeing Slimming Advertisements

After seeing slimming advertisements, $63 \%$ of the respondents were not sure if they felt jealous or didn't have any change in them, so they opted for neutral. While $24 \%$ confidently said they had no change in their emotions, $10 \%$ agreed that they felt jealous. Very few respondents said they felt inferior. From this data, we can note that slimming advertisements may affect the emotions of people.

\subsubsection{IMPACT OF SLIMMING ADVERTISEMENTS ON THEIR DIET OR EATING BEHAVIOUR}

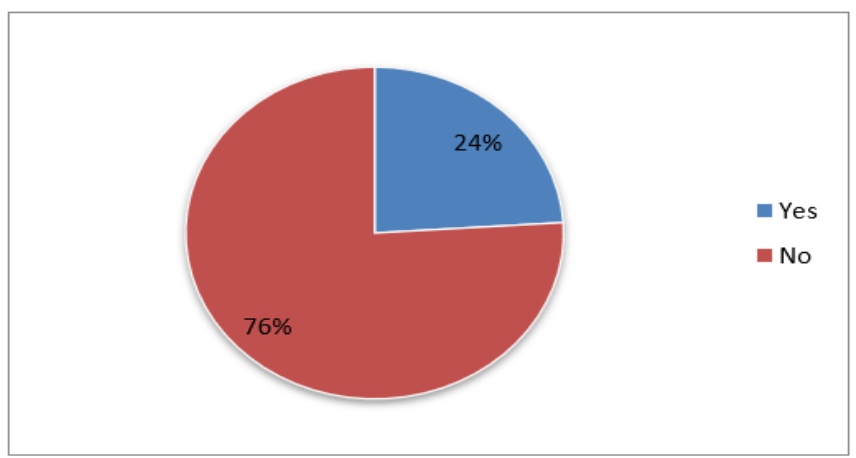

Figure 5 Impact of Slimming Advertisements on their diet or eating behaviour

The above data shows that $76 \%$ of the respondents were confident that the advertisements never had any impact on their diet or eating behaviour. The rest $24 \%$ of the respondents had the impact. This reveals that not many people have 
changed their regular eating behaviour, but few people had the impact. There are chances of these few people getting affected with eating disorders like Anorexia Nervosa and Bulimia Nervosa.

\subsubsection{WHETHER THE PROMISING MESSAGES OF THESE ADVERTISEMENTS IS TRUSTWORTHY}

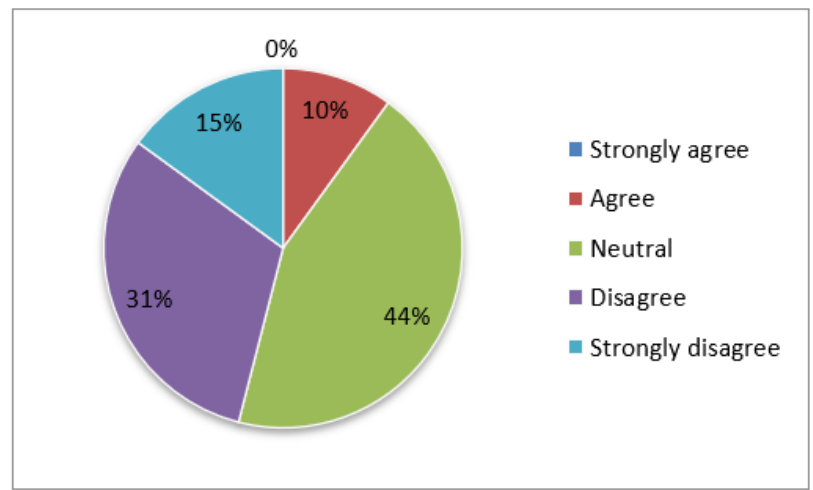

Figure 6 Whether the promising messages of these Advertisements is Trustworthy

Most of the respondents felt that the promising messages found in these advertisements were not trustworthy. $44 \%$ of the respondents said they neither agree nor disagree by opting for neutral. $31 \%$ said that they disagree while $15 \%$ said they strongly disagree. Very few people said they agree the fact. This represents that most of the people don't trust these advertisements since they are exaggerated and do not hold any ethical value.

\subsubsection{WHETHER THEY COMPARE THEMSELVES WITH MODELS USED IN THE ADVERTISEMENTS}

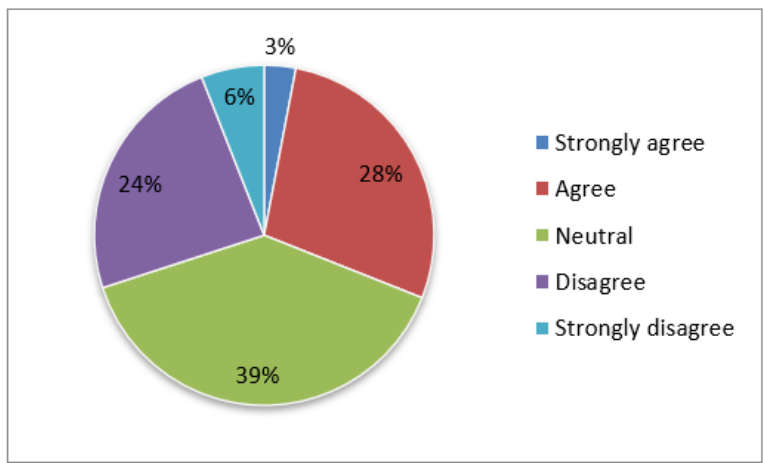

Figure 7 Whether they compare themselves with models used in the Advertisements

Many respondents were not ready to accept that they compared themselves with the models used in these advertisements as $39 \%$ of them opted for neutral. But $28 \%$ of them agreed with this fact followed by $24 \%$ who disagreed with the same. 
Few of them strongly disagreed and very few of them strongly agreed. This data shows that people are influenced by the models used in these advertisements.

\subsubsection{THE MAIN TARGET OF SLIMMING ADVERTISEMENTS}

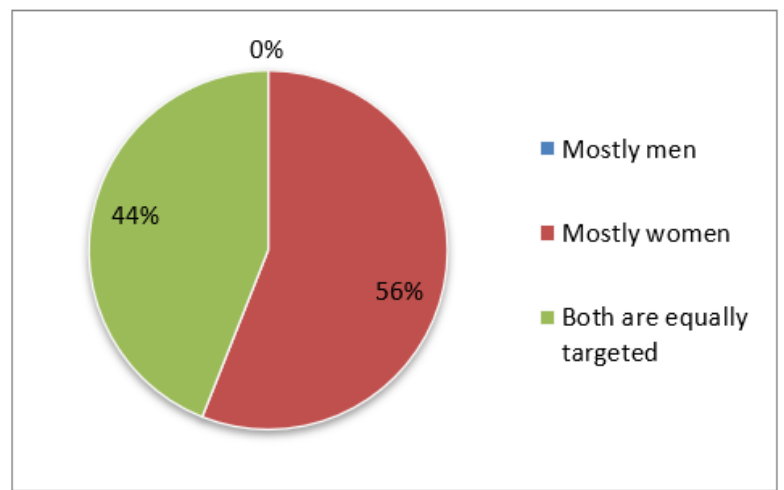

Figure 8 The main target of Slimming Advertisements

For this question, there are mixed response from the respondents as $56 \%$ said that the advertisements mostly target only women and $44 \%$ said that both men and women are equally targeted. It was also noted that not even a single respondent felt that the target are mostly men. This clearly shows that mostly women are targeted by many slimming advertisements.

\subsubsection{WHETHER THEY HAVE TRIED, WERE TRYING OR MIGHT TRY AFTER SEEING THESE ADVERTISEMENTS}

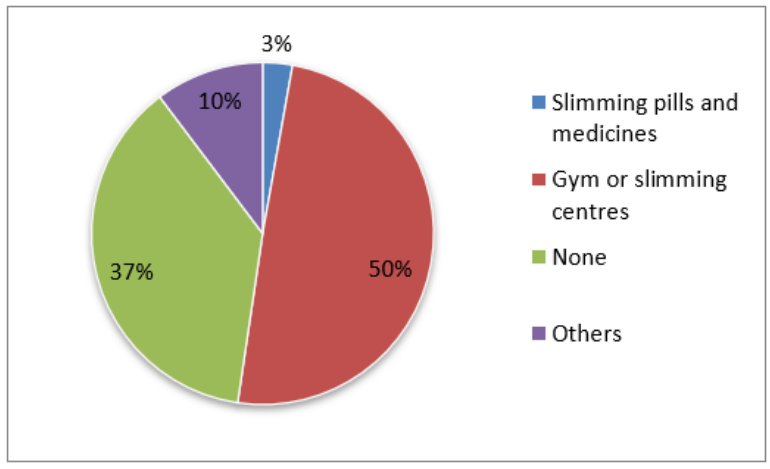

Figure 9 Whether they have tried, were trying or might try after seeing these Advertisements

For the question on which product or service they have tried, were trying or might try after seeing these advertisements, $50 \%$ of them responded with gym or slimming centres. This data shows that gym and slimming centres are very popular among men and women. Many respondents said they haven't tried any product or service to maintain their weight and fitness. Very few respondents said they used 
slimming pills and medicines. Some of the other respondents said they used Kellogg's, Herbalife, and Get Trim.

\section{CONCLUSION}

This study focused on the advertisements related to slimming products appearing in print media. Slimming advertisements can be frequently noticed in newspapers and magazines. These advertisements can easily influence people particularly youngsters. The impact it has created on them cannot be overlooked. False or misleading advertisements can create negative effects on the readers. Starks et al. (2004).

From this study it can be concluded that slimming advertisements use print media as an effective tool to persuade the target audience through repetitive advertisements. Misleading claims and exaggerated images are commonly used by the advertisers to lure youngsters and it has created a big impact on them. Eye catching headlines, graphics, content, and images are commonly used in these advertisements to capture the attention of readers. Women are the primary target of these advertisers since health consciousness and the passion to become slim is more among them compared to men. Further, it also influences both men and women and cultivates appearance dissatisfaction in them. Unless the publishers and government start to review questionable slimming advertisements and take disciplinary action, the slimming product selling industries will persist to endure from a deficient. Finally, individuals should also be aware of the lack of credibility in these advertisements and should know how to filter the communication passed through these advertisements.

\section{REFERENCES}

Anderson, J. Young, L. and Roach, J. (2008). Weight Loss Products and Programs, Colorado State University Extension.

Bansal, R. K. Mistry, N. Kargathra, V. Kosambi, A. Lathiya, P. Raval, B. (2008). Unsupervised Weight Losing Patterns by Anorexic Subjects : A Cause for Concern, Journal of Association of Physicians of India, 56, 241-258.

Bansal, R. K. Kumar, S. Desai, M. A. Patel, S. J. Patel, A.H. (2010). Body Shape Perceptions, Journal of Applied-Basic Medical Sciences, 12, 125-146.

Bordo, S. (2003). Unbearable Weight : Feminism, Western Culture, And The Body (10th Anniversary ed.) Berkeley, CA : University of California Press.

Brown, S. (2005). Body/Image/Narrative : Contemporary Rhetoric of Body Shape And Size, Baltimore, US : University of Maryland.

Cohen, B. (2006). Media Exposure and the Subsequent Effects on Body Dissatisfaction, Disordered Eating, and Drive for Thinness : A Review of the Current Research, Mind Matters : The Wesleyan Journal of Psychology, CT.

Conover, T. (1995). Graphic Communications Today. St. Paul, Minnesota : West Publishing Company.

Diaz, A. (2011). Manipulation of Teenagers Through Advertising : A Critical Discourse Approach, University of Valencia, 6, 48-60. 
Grogan, S. (2008). Body Image Understanding Body Dissatisfaction in Men, Women, And Children, Second Edition.

Hobbs, R. Broder, S. Pope, H. and Rowe, J. (2006). How Adolescent Girls Interpret Weight-Loss Advertising, Health Education Research, Theory and Practices, Advance Access publication, 5, 301-312. https://doi.org/10.1093/her/cyl077.

Kapadia, M. and Kalidas, (2009). Body Image in Indian Women as Influenced by the Indian Media Texas Woman's University.

Leon, S.G. and Kanuk, L. (2004). Consumer Behavior, (8th ed.), Pearson Prentice Hall, New Delhi, India.

Munshi, S. (2001). Images of the 'Modern Woman' in Asia : Global Media, Local Meanings, Richmond, Surrey : Curzon Press.

Starks, M. Gomez, L. Chambliss, H. and Martin, S. (2004). Weight - Related Words Associated With Figure Silhouettes, Body Image : An International Journal of Research, 58-70. 